\title{
The first female academicians in Turkish veterinary education*
}

\author{
Özgül KÜÇÜKASLAN ${ }^{1}$, R. Tamay BAŞAĞAÇ GÜL ${ }^{2}$, Aytaç ÜNSAL ${ }^{2}$ \\ ${ }^{1}$ Dicle University, Faculty of Veterinary Medicine, Department of Veterinary History and Deontology, Diyarbakır; ${ }^{2}$ Ankara \\ University, Faculty of Veterinary Medicine, Department of Veterinary History and Deontology, Ankara, Turkey.
}

\begin{abstract}
Summary: Although women in Turkey were first given the opportunity to attend schools of higher education in 1914, the number of female students in higher education increased rapidly through socio-economic and cultural reforms, which were carried out following the establishment of the Turkish Republic in 1923. Merver Ansel, who graduated from the Veterinary School in Ankara in 1935, became the first female veterinarian in Turkey. In 1938, Abide Koray was appointed as research assistant at the Institute of Internal Diseases of this School thus, women have taken place in academic life. With this study, which was aimed at providing data on the first female academicians in Turkish veterinary education, 19 brief biographies were prepared by using archival documents, memoirs, oral sources and 16 photos have been reached. The biographies revealed that females started their academic career in veterinary medicine three years after the first woman graduated from the veterinary school in 1935. It was also determined that almost all female academicians carried out their academic careers in basic and pre-clinical sciences since 1947 and 1950 respectively; but after Koray (1938), the second woman academician could begin her career in clinical sciences in 1984.
\end{abstract}

Keywords: Academician, female, Turkey, veterinary medicine.

\section{Türk veteriner hekimliği öğretiminde ilk kadın akademisyenler}

Özet: Türkiye'de kadınlara yükseköğrenim firsatı ilk kez 1914 yılında verilmiş olmasına rağmen, yükseköğretimdeki kadın öğrenci sayıs1 1923 yılında Cumhuriyetin kurulmasından sonra gerçekleştirilen sosyo-ekonomik ve kültürel reformlarla birlikte hızlı bir artış gösterdi. Ankara'da bulunan Veteriner Okulundan 1935 yılında mezun olan Merver Ansel, Türkiye'nin ilk kadın veteriner hekimi oldu. Bu Okulun Dahilî Hastalıklar Enstitüsüne 1938 yılında Abide Koray’ın asistan olarak atanmasıyla birlikte kadınlar akademik yaşamda da yer almaya başladı. Türk veteriner hekimliğinde ilk kadın akademisyenler hakkında veri sağlamak amacıyla gerçekleştirilen bu çalışmada arşiv belgelerinden, anılardan ve sözlü kaynaklardan yararlanılarak 19 kısa biyografi hazırlandı; 16 fotoğrafa ulaşıldı. Biyografiler, ilk kadın veteriner hekimin mezuniyetinden (1935) üç yıl sonra kadınların veteriner hekimliği alanında akademik yaşama adım attıklarını; 1947 yılından itibaren temel bilimlerde ve 1950 yılından itibaren de klinik öncesi bilimlerde kariyer yaptıklarını gösterdi. Koray'dan (1938) sonra klinik bilimlerdeki ilk kadın akademisyen kariyerine ancak 1984 yılında başlayabildi.

Anahtar sözcükler: Akademisyen, kadın, Türkiye, veteriner hekimliği.

\section{Introduction}

The "Tanzimat" or Reform Period of 1839-1876 marks the beginning of westernization in Turkey. Education of women was one of the most vital issues of this period $(11,25)$. In addition to the primary schools, where previously both boys and girls could attend, women first begun to be trained as midwives at the Medical School in 1842, the first secondary school (Kız Rüşdiyyesi) was founded in 1859 , a vocational school for women $(K l z$ Sanayi Mektebi) was established in 1869 and a training college for women teachers (Dârülmuallimât) begun its educational activities in $1870(2,12,17,18)$. In the same year, with the declaration of the "Regulation of Public Education" (Maârif-i Umumiyye Nizamnâmesi), primary education was made compulsory for girls between the age of six and ten (23). In addition to these developments, women were first given the opportunity to attend schools of higher education in 1914 and were first allowed to apply for admission to the Faculties of Law and Medicine in Istanbul University in $1922(5,24)$. However, only a limited number of female students had been able to enrol in these faculties.

After the establishment of the Turkish Republic, women, who confronted gender-based discrimination for several years, gained equality with men in economic, socio-political rights and cultural opportunities, provided by the revolutions and reforms of Atatürk. The doors of health sciences occupations such as medicine, dentistry,

\footnotetext{
* This article, which contains the initial results of a project that is currently underway, was developed on the basis of the presentation "The first female academicians in the Turkish Higher Education of Veterinary Medicine" which was presented at the $32^{\text {nd }}$ World Veterinary Congress, held in Istanbul in September 13 to17, 2015.
} 
pharmacy and veterinary medicine were opened to women. Merver Ansel, who graduated from the Veterinary School $^{1}$ (VSA) in Ankara became the first female veterinarian of Turkey in 1935 (3, 7, 10, 20). Abide Koray, who was appointed as the research assistant at the Institute of Internal Medicine of this School in 1938, became the first female veterinarian who started her academic career $(13,20)$.

The worldwide feminization of veterinary profession, numerical data on females in Turkish veterinary medicine and several biographical studies on female veterinarians in Turkey have been the subject of limited number of publications $(5,9,10,16,21)$. The purpose of the present study is to provide holistic information on the first female academicians in Turkish veterinary education and to make contributions to the studies on veterinary history in specific manner and women studies in general.

\section{Materials and Methods}

The main sources of this research were personnel files obtained from the Deanery archives of veterinary schools, which were active as of March 2015 and the Biography Archive of the Turkish Veterinary Medicine (BA-TVM) at the Department of Veterinary History and Deontology (DVH\&D), VSA. In addition to the archival documents, periodicals and books related to the subject, memoirs and oral sources were also used. During content analysis, it was treated carefully to include only those who graduated from veterinary schools and also started their academic stages as "research assistant" position. Those who graduated from other schools and have careers in veterinary schools and those who continued their $\mathrm{PhD}$ and master studies without assignment to research assistant position were ignored. It had also tried to reach the academic activities and publications of the first female academicians who were the subjects of this study, but a holistic data could not be found. Therefore, incomplete

1 This School was active as one of the schools of the Higher Agricultural Institute between the years 1933-1948; it became affiliated with Ankara University in 1948, and remained the sole veterinary institution until 1970 . Therefore in the text and tables VSA abbreviation was preferred for referring this School.

2 Personnel Files of Kamuran Ertürk, Nihal Erk, Belma Alabay and R. Merih Hazıroğlu, BA-TVM, the DVH\&D and the Deanery Archive, Veterinary School, Ankara University, Ankara.

3 Personnel Files of Nermin Tolgay, Nahide Özgümüş, Şenay Berkin, Asuman Toker and Emine Baydan, BA-TVM, the DVH\&D and the Deanery Archive, Veterinary School, Ankara University, Ankara; Personnel File of Gülten Köksal, BA-TVM, the DVH\&D, Veterinary School, Ankara University, Ankara.

${ }^{4}$ Personnel Files of Abide Koray, A. Perran Gökçe and Ongun Uysal, BA-TVM, the DVH\&D and the Deanery Archive, data obtained from the limited number of personnel files, were excluded from the study. Following content analysis, data were categorized and shown chronologically in the table that was designed regarding existing departments and divisions of veterinary schools in Turkey. The current names of these academic units were used in order to be intelligible. Finally, the results were discussed and the conclusions were drawn.

\section{Results}

The biographic data, academic stages and current situations of the first female academicians (Figures1-16), who started their academic activities at the Division of Basic Sciences ${ }^{2}$, the Division of Pre-clinical Sciences ${ }^{3}$, Division of Clinical Sciences ${ }^{4}$, the Division of Food Hygiene and Technology 5 and the Division of Animal Husbandry and the Animal Nutrition ${ }^{6}$ are presented in Table 1.

As it can be seen in the Table 1, the first female academician of Turkish veterinary medicine was Abide Koray (Figure 9), who was appointed as the research assistant at the Department of Internal Medicine of Division of Clinical Sciences of the VSA in 1938. Koray completed her PhD thesis in 1944, so she had succeeded in becoming the first woman awarded with "Doctor of Philosophy" degree in this field in Turkey. Additionally, Kamuran Ertürk (Figure 1) from the Department of Physiology (1947) and then from the Department of Biochemistry (1952) was the first female academician at the Division of Basic Sciences; Nermin Tolgay (Figure 5) from the Department of Parasitology (1950) was the first female academician at the Division of Pre-clinical Sciences; Nahide Özgümüş ${ }^{7}$ from the Department of Food Hygiene and Technology (1951) was the first female academician at the Division of Food Hygiene and Technology and Hümeyra Özgen ${ }^{8}$ (Figure 13) from the Department of Animal Nutrition and Nutritional Diseases (1962) was the first female

Veterinary School, Ankara University, Ankara; the CV of Huriye Horoz Kaya was obtained from Prof. Kaya.

5 Personnel File of Nahide Özgümüş, BA-TVM, the DVH\&D and the Deanery Archive, Veterinary School, Ankara University, Ankara; Personnel File of Nevra Aydemir Celep, the Personnel Archive of the Veterinary School, Kafkas University, Kars.

6 Personnel Files of Hümeyra Özgen, Öznur Poyraz, Gül Latzel and Bengi Çınar Kul, BA-TVM, the DVH\&D and the Deanery Archive, Veterinary School, Ankara University, Ankara.

7 Nahide Özgümüş, whose photograph was not found, was the first assistant of both Department of Microbiology (1951) and Department of Food Hygiene and Technology (1952). But, Department of Microbiology is currently located within Division of Pre-clinical Sciences therefore Nermin Tolgay was shown as the first female academician at this Division.

8 Personnel File of Hümeyra Özgen, BA-TVM, the DVH\&D and the Deanery Archive, Veterinary School, Ankara University, Ankara. 

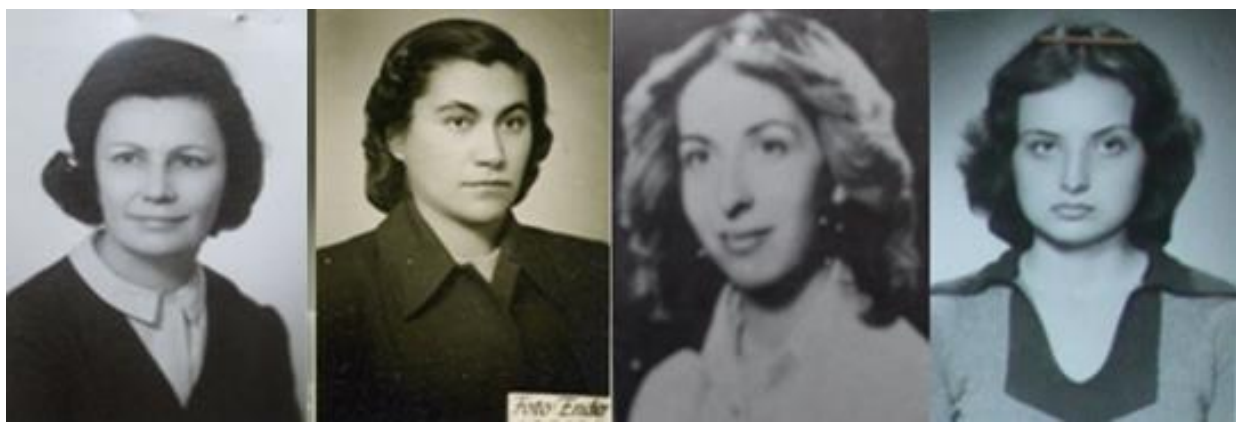

Figure 1-4. The first female academicians of the Division of Basic Sciences.

Kamuran Ertürk 1947, Nihal Erk 1950, Belma Alabay 1978, R. Merih Hazıroğlu 1981.

Şekil 1-4. Temel Bilimler Bölümünün ilk kadın akademisyenleri.

Kamuran Ertürk 1947, Nihal Erk 1950, Belma Alabay 1978, R. Merih Hazıroğlu 1981.

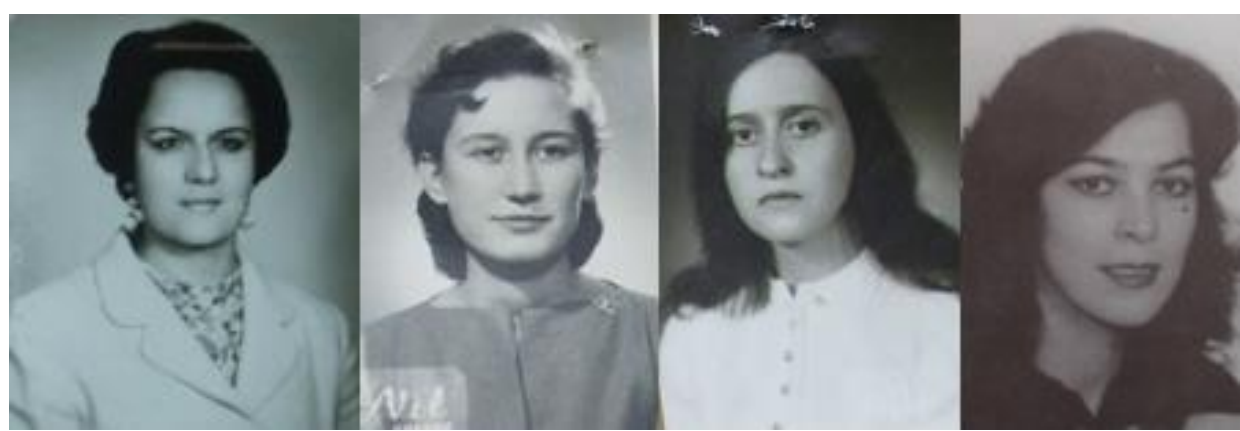

Figure 5-8. The first female academicians of the Division of Pre-clinical Sciences.

Nermin Tolgay 1950, Şenay Berkin 1967, Asuman Toker 1977, Emine Baydan 1982.

Şekil 5-8. Klinik Öncesi Bilimler Bölümünün ilk kadın akademisyenleri.

Nermin Tolgay 1950, Şenay Berkin 1967, Asuman Toker 1977, Emine Baydan 1982.

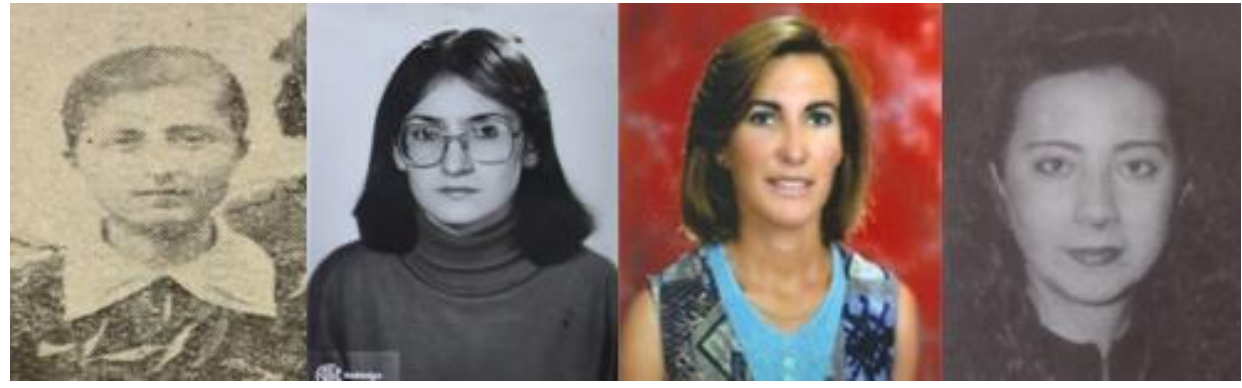

Figure 9-12. The first female academicians of the Division of Clinical Sciences.

Abide Koray 1938, A. Perran Gökçe 1984, Huriye Horoz Kaya 1984, Ongun Uysal 1986.

Şekil 9-12. Klinik Bilimler Bölümünün ilk kadın akademisyenleri.

Abide Koray 1938, A. Perran Gökçe 1984, Huriye Horoz Kaya 1984, Ongun Uysal 1986.

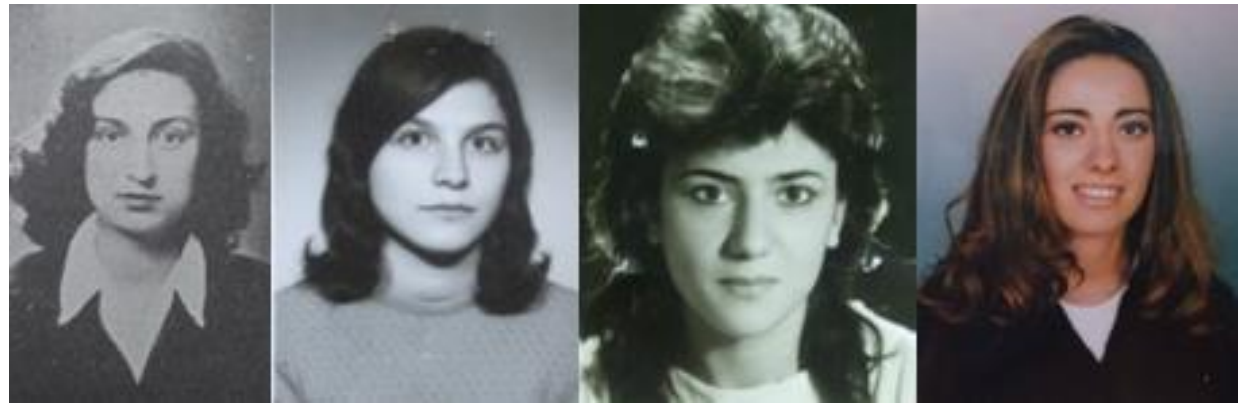

Figure 13-16. The first female academicians of the Division of Animal Husbandry and Animal Nutrition. Hümeyra Özgen 1962, Öznur Poyraz 1981, Gül Latzel 1992, Bengi Çınar Kul 2007.

Şekil 13-16. Zootekni ve Hayvan Besleme Bölümünün ilk kadın akademisyenleri.

Hümeyra Özgen 1962, Öznur Poyraz 1981, Gül Latzel 1992, Bengi Çınar Kul 2007. 


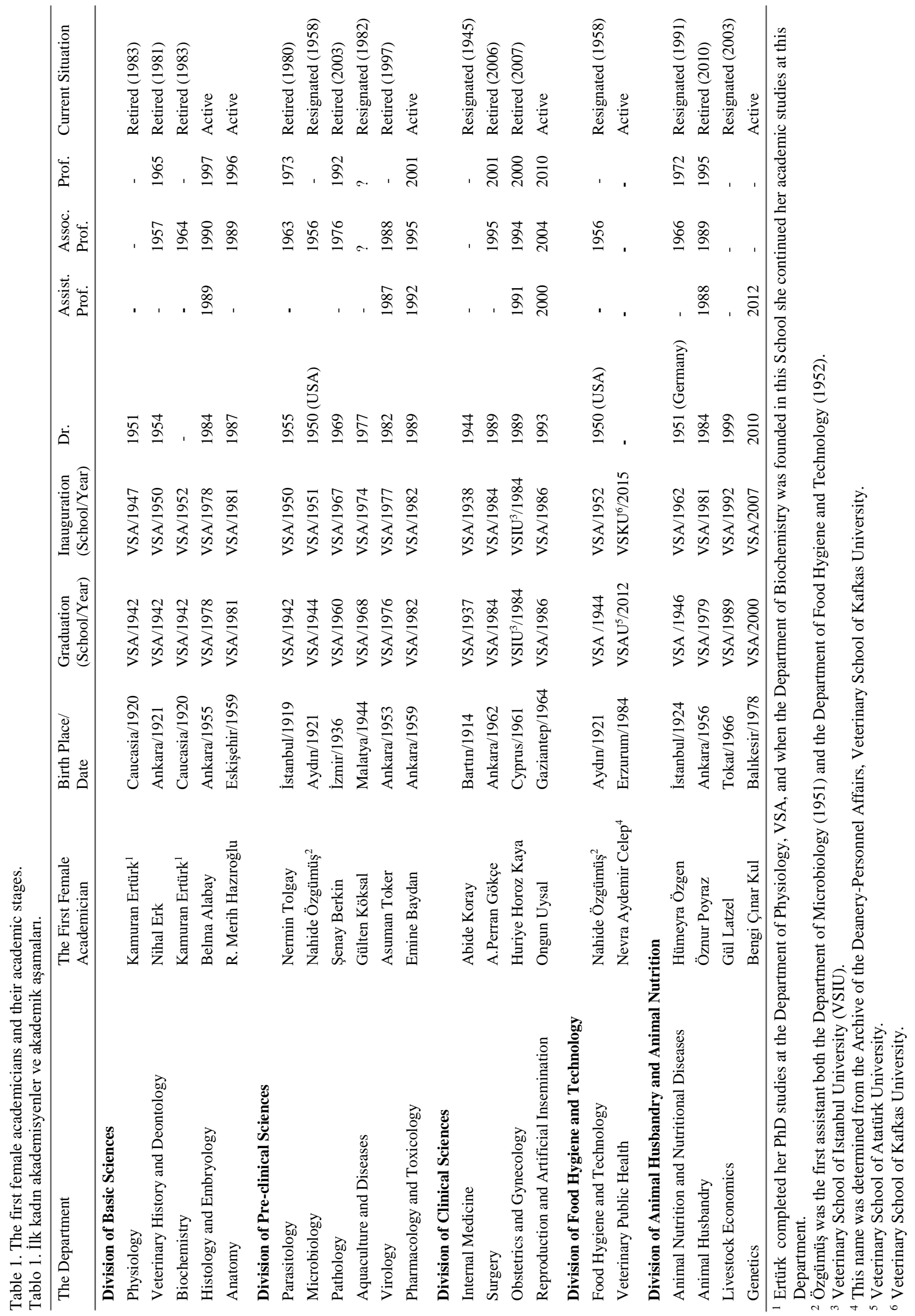


academician at the Division of Animal Husbandry and Animal Nutrition. Hümeyra Özgen also became the Dean of the Veterinary School of Firat University (1978-1982) and the Veterinary School of Selçuk University (19821991) $(27,28)$ respectively and so as the first female veterinarian who was carried out deanship position in Turkey and she went down in Turkish veterinary history.

\section{Discussion and Conclusion}

Although in one of the related publications (13), İffet (Çakmak) Turgay was pointed as if she were the first female research assistant in the field of veterinary medicine in Turkey, there has been no data in her personnel file ${ }^{9}$ to verify this information. In face to face interviews, Prof. Dr. Ahmet Noyan ${ }^{10}$, who left Department of Physiology in 1973, clarified this subject and informed that İffet (Çakmak) Turgay had never been an assistant at the Department of Physiology and just worked as a volunteer. Noyan also stressed that he was appointed as the research assistant instead of Turgay to this Department in 1943. This statement could be important if it showed a preference of man to woman as an academic person. On the other hand until proven otherwise, Abide Koray should be accepted as the first research assistant in veterinary medicine in Turkey as mentioned in limited publications $(6,20)$ before. The present study also demonstrates that Abide Koray was the first female to get the Doctor of Philosophy Degree (1944) in the field of veterinary medicine in Turkey. Başağaç et al. (6) informed that clinical disciplines of Turkish veterinary medicine resisted the inclusion of females until recently and they gave examples to support this reality. Considering this situation, it should be said that Koray's PhD study was an important challenge to this "male dominated" profession during that time.

According to Menteş et al. (20), the first female veterinary lecturer in Turkey was Nihal Erk, who had obtained the "associate professor degree" in the field of Veterinary History and Deontology in 1957. This data was also previously given by Başağaç et al. (6) too. But, the personnel file ${ }^{11}$ of Nahide Özgümüş definitely shows that it was Özgümüş, who had obtained the associate professor degree in the field of Food Hygiene and Technology in 1956. This position of Özgümüş is also supported indirectly by some publications $(13,14,16)$. So, this comment is clearly visible for the first time in present article.

In Kocacık and Dölen's study (16) mentioned above, the number of female teaching fellows were given and

\footnotetext{
9 The CV of Iffet (Çakmak) Turgay, BA-TVM, the DVH\&D Veterinary School, Ankara University, Ankara.

10 These interviews with Emeritus Prof. Dr. Ahmet Noyan were carried out on the $23^{\text {rd }}$ December, 2010. The written records of
}

four names (Adnan Gürkök, Fahriye Öğüş, Nihal Erk, Nahide Özgümüş) were interpreted as if they were teaching fellows between the years 1946 and 1947. In the School's 1946 Yearbook (4), Adnan Gürkök and Fahriye Öğüş were seen as intern assistants. In some publications $(13,21)$ it was determined that they were the staff of Ministry of Agriculture and they were only trained as specialists. Therefore, it is thought that these two names should not be included in the lists of teaching fellows and first female academicians in Turkish veterinary medicine.

In his study Öncel (22) reveals the first females in the health science professions (medicine, veterinary medicine, dentistry and pharmacy) and he shows that among them it was veterinary medicine which women entered more recently. According to him, this situation stemmed from the idea that veterinary medicine -as a profession - was not suitable for women. This comment must be the result of the approaches associated with the requirement of active interactions between veterinarians and patients. Because many people believe that these kinds of interactions especially during clinical practices - often require "physical power", which only men have $(15,19,26)$. Some researches $(1,8)$ also support that women are excluded from male dominated areas such as clinics. This situation is clearly seen in veterinary surgery, of which doors were opened to female veterinarians in Turkey in the 1980s (6). In one of the publications written by Başağaç et al. (5), gender distribution of graduates from the veterinary schools in Turkey between the years 1935-2005 was given. If the total annual number of women starting their academic life in this period were known, it would be possible to calculate the participation rates of women in academic life in the field of veterinary medicine in Turkey. Without these data, it is not possible to comment on this subject. But still based on the annual number of graduates given in this publication (5), it can be said that despite gradual increase in the number of female graduates, the first female veterinarians had begun their academic lives at different branches of veterinary medicine in Turkey one by one and over a wide range of time.

The present study shows that 17 of 19 first female academicians in Turkish veterinary education were graduated from the VSA and began their careers at this School (Table 1). This situation obviously shows that for their careers 18 of these 19 females preferred their own school that they graduated. By the way it should also be considered that this School remained the sole veterinary institution until 1970 in Turkey (4), and seven of above

the interviews are kept in the DVH\&D Veterinary School, Ankara University, Ankara.

${ }^{11}$ Personnel File of Nahide Özgümüş, BA-TVM, the DVH\&D and the Deanery Archive, Veterinary School, Ankara University, Ankara. 
mentioned females already began their careers before 1970 (Table 1).

In conclusion, the first woman started her academic career in Turkish veterinary medicine within a short period after the graduation of the first female veterinarian Merver Ansel. The biographies, prepared with this study show that 17 of 19 first female academicians were graduated from the VSA and one was graduated from the VSIU. These 18 females continued their academic career at the school they graduated. Abide Koray was the first woman research assistant and the first woman received a $\mathrm{PhD}$ degree in the field of veterinary medicine, Nahide Özgümüş was the first female teaching fellow, Nihal Erk was the first professor and Hümeyra Özgen was the first female dean in this field in Turkey. The biographies revealed that in early period while female academicians started their academic careers in basic or pre-clinical sciences; they started their careers in clinical sciences in most recent years.

\section{References}

1. Adudu OP, Adudu OG, Egbagbe EE (2006): Perception of female doctors' clinical practice and teaching in anaesthesia and other medical specialties by medical students in Nigeria. CMS UNIBEN JMBR, 5, 7-12.

2. Akyüz Y (1994): Türk Ĕ̌itim Tarihi (Başlangıçtan 1993 'e). Kültür Koleji Yayınları, İstanbul.

3. Anonim (1935): Yeni tayinler. Türk Baytarlar Cemiyeti Mecmuas1, 5, 934.

4. Anonim (1946): YZE Veteriner Fakültesi Yıllı̆̆ı. Ankara Yüksek Ziraat Enstitüsü Basımevi, Ankara.

5. Başağaç Gül RT, Özkul T, Akçay A, et al. (2008): Historical profile of gender in Turkish veterinary education. JVME, 35, 305-309.

6. Başağaç Gül RT, Küçükaslan Ö, Yerlikaya N (2010): Female Veterinary Surgeons in Turkey. XXXIX. International Congress of the World Association for the History of Veterinary Medicine and III. National Symposium of the Turkish Association for the History of Veterinary Medicine and Professional Ethics, 20-23 September 2010, Antalya-Turkey, 199-204.

7. Bekman M (1940): Veteriner Tarihi. Ankara Basım ve Cilt Evi, Ankara.

8. Çobanoğlu N, Aydoğdu İB (2004): Tip Alaninda Toplumsal Cinsiyet Kavramının Tibbi Etik Boyutları. Kadın Çalışmalarında Disiplinlerarası Buluşma, 01-04 Mart 2004 Sempozyum Bildiri Metinleri, Cilt: 3, Yeditepe Üniversitesi Yayınları, İstanbul.

9. Dinçer F (2014): Bir Ömür Böyle Geçti - Prof. Dr. Nihal Erk'in Yaşamindan Kesitler. IV. Ulusal Veteriner Hekimliği Tarihi ve Mesleki Etik Sempozyumu, Samsun, 39-53.

10. Doğanay Feldhaus S, Özgür A (1991): Diestellung der fraualstierärztin in der Türkei. Vet Journal für den Veterinär, VI, 30-35.

11. Ediz Z (1995): Kadın Tarihine Bir Bakış. Birinci Baskı. Adım Yayıncılık, İstanbul.
12. Ergin O (1977): Türk Maarif Tarihi. Eser Matbaas1, İstanbul.

13. Erk N, Dinçer F (1970): Türkiye'de Veteriner Hekimlik Ögrretimi ve Ankara Üniversitesi Veteriner Fakültesi Tarihi. Ankara Üniversitesi Veteriner Fakültesi Yayınları: 259, Ankara Üniversitesi Basımevi, Ankara.

14. Erk N (1973): Türkiye Cumhuriyetinin Illk 50 Yllında (19231973) Veteriner Hekimlik Öğretiminin Gösterdiği Gelişmeler, Ankara Üniversitesi Veteriner Fakültesi Yayınları, Ankara.

15. Irvine L, Vermilya JR (2010): Gender work in a feminized profession-the case of veterinary medicine, Gender and Society, 24, 56-82.

16. Kocacık ET, Dölen E (2014): Yüksek Ziraat Enstitüsü ve Ankara Üniversitesi Veteriner Fakültesi'nde Kız Öğrenciler ve Kadın Öğretim Üyeleri 1933-1972. IV. Ulusal Veteriner Hekimliği Tarihi ve Mesleki Etik Sempozyumu, Samsun, 77-100.

17. Kurnaz Ş (1991): Cumhuriyet Öncesinde Türk Kadını. T.C. Başbakanlık Aile Araştırma Kurumu Başkanlığı Yayınları, 2. Bask1. Ankara.52-53.

18. Kurnaz Ş (1996): II. Meşrutiyet Döneminde Türk Kadını. Milli Eğitim Basımevi, İstanbul, s.101-107.

19. Kuzuca İG (2007): Türkiye'de Tipta Uzmanlık ve Akademisyenlik Aşamalarında Cinsiyetçi Yaklaşımlar, Ankara Üniversitesi Sosyal Bilimler Enstitüsü, Yüksek Lisans Tezi, Ankara.

20. Menteş A, Özgür A, Arslan ES (1998): Türk Veteriner Hekimliğinde Kadınlar ve Sağllk Alanına Katkıları. Sağlık Alanında Türk Kadını, Form Reklam Hizmetleri, İstanbul.

21. Merdivenci A (1976): Türkiye'de Veteriner Parazitoloji Tarihi. Hilâl Matbaacılık, İstanbul.

22. Öncel Ö (1976): Sağllk alanında ilk kadınlarımız. Dirim, 51, 355-365.

23. Özalp R, Ataünal A (1977): Türk Millî Ĕ̆itim Sisteminde Düzenleme Teşkilâtı. Birinci Baskı, Millî Eğitim Basımevi, İstanbul.

24. Sarı N (1998): Osmanlı Sağlık Hayatında Kadının Yerine Kısa Bir Bakış. Sağlık Alanında Türk Kadını; Cumhuriyet'in ve Tıp Fakültesi'ne Kız Öğrenci Kabulünün 75. Y11, İstanbul.

25. Taşkıran T (1973): Cumhuriyetin 50. Yılında Türk Kadın Hakları. Başbakanlık Basımevi, Ankara.

26. Yapıcı G, Uğurhan Torlak F, Ögenler O, et al. (2010): Mersin'de çalışan kadın hekimlerin eğitim ve meslek yaşamlarında ayrımcılık deneyimleri. Mersin Univ Saglık Bilim Derg, 3, 22-29.

27. Yaşar A (1995): Selçuk Üniversitesi Veteriner Fakültesi'nin kuruluşu ve ilk on yıllık gelişimi. Veteriner Bilimleri Dergisi, 11, 131-139.

28. Yerlikaya H (1982): Elazı̆̆ Veteriner Fakültesinin Kuruluşu, On Ylllı Gelişim ve Türk Veteriner Hekimlik Ögrretimindeki Yeri. Fırat Üniversitesi Veteriner Fakültesi, Doktora Tezi, Elazı ̆̆.

Geliş tarihi: 28.02.2016 / Kabul tarihi: 01.01.2017
Address for correspondence:
Assist. Prof. Dr. Özgül Küçükaslan
Dicle University, Faculty of Veterinary Medicine,
Department of Veterinary History and Deontology,
21280 Diyarbakır, Turkey.
e-mail: ozgul.kucukaslan@dicle.edu.tr 